\title{
The emergence of the private entrepreneur in reform era China: Re-birth of an earlier tradition, or a more recent product of development and change?
}

\begin{abstract}
A private sector that now dominates economic activity has emerged in China since 1978, even though many of the essential institutions for market competition have been lacking or are under-developed. We find that there is no evidence that this upsurge of entrepreneurship is a re-birth of an earlier tradition. Instead, the dynamics of entrepreneurial emergence can be attributed to reforms and institutional changes that have occurred since 1949, both before and after the introduction of economic reforms in late 1978. We find that these institutional changes have been evolutionary, adapting to as well as shaping emerging forms of economic activity, including entrepreneurship. Our conclusion is that these dynamics of adaptation and evolution produce 'rule ambiguities' within the institutional framework that create opportunities for entrepreneurs as well as making these opportunities vulnerable to further institutional change.
\end{abstract}

Key words: China, entrepreneurship, institutional adaptation, private sector, rule ambiguities.

\section{Introduction}

A central feature of China's recent economic development has been the emergence of a private sector that generates the majority of the country's economic activity and growth. This 
emergence has occurred even though China has lacked key market institutions during much of the reform period, in particular: established commercial and contract laws from which entrepreneurs can seek redress when contracts are not honoured; and legally enforceable and recognised private property rights that provide protection of the entrepreneur's assets and returns. ${ }^{1}$ The rapid growth of private sector entrepreneurship in China cannot be attributed to the types of market institutions that create conducive conditions for entrepreneurship in most developed economies. ${ }^{2}$ Instead, growth has preceded the introduction of the market institutions that are considered essential to private sector development. Why, then, did a dynamic private sector emerge when China lacked market institutions deemed necessary for entrepreneurship? ${ }^{3}$

One explanation would be the re-emergence of a pre-revolutionary legacy of enterprise during China's recent reform period, when conditions became more conducive to entrepreneurship than they had been during the preceding period of central planning. ${ }^{4}$ We reassess the notion that such a legacy explains the rise of an entrepreneurial private sector in today's China. In particular, we critique assertions that China's Confucian tradition has served as a foundation for entrepreneurial emergence during the reform period. ${ }^{5}$

Rather than reach back into pre-revolutionary China, we propose that private sector emergence needs to be understood within the broader context of the evolution of market mechanisms and regulation during the post-1978 reform period. This focus on structural changes to the ways in which the economy has been organised during the reform period lends itself to an institutionalist perspective. Institutionalist approaches, derived from the New Institutional Economics work of North and others, consider the 'rules of the game' of market exchange and how these rules are governed and sanctions taken should they be broken. ${ }^{6}$ In other words, institutionalist perspectives focus on the extent to which market mechanisms 
exist that enable efficient and transparent exchange. Where institutions enable market exchange, conditions are conducive for entrepreneurs to operate in a predictable and consistent environment. ${ }^{7}$ However, where they are not formed, or do not enable exchange, incentives are created that produce destructive or non-productive entrepreneurship. ${ }^{8}$ The development of institutions that have variable effects on entrepreneurship has become an emergent area of research on private sector development in transition economies, in large part because experiences in the former Soviet Union and countries such as China show that development of market institutions is the most challenging component of market reform and

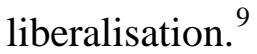

Institutional perspectives on entrepreneurship in China recognise the wider context within which the private sector developed, situating development of market institutions alongside changes in ownership from public to private, and significant economic liberalisation and reform. ${ }^{10}$ The positive effects of market liberalisation - including for example greater productivity, more competition and innovation, and increased demand from consumers and businesses - have created conducive conditions for private sector development. In addition, the state has stimulated growth through investment in infrastructure, development and acquisition of technologies, and promotion of key industries and enterprises. As such, the emergence of the private sector can be considered a product, and feature, of overall economic growth and the changes this has brought to the Chinese economy, as well as a dynamic enabled by particular institutional configurations during China’s reform period.

Within this broader context of national growth, we explore three key institutional features of the early reform period that enabled entrepreneurial emergence: adaptation of institutions and mechanisms developed for the planned economy to market governance; contracting out rights of production from the state to the individual; and hybrid forms of governance, where 
ownership remains with the state but management is contracted to the private sector.

Crucially, contracts and hybrid ownership-management arrangements offered an intermediate position between public and private ownership, so avoiding ideological challenges to the emergence of an increasingly marketised economy.

We note that hybrid ownership arrangements were discouraged after the major reform of the state-owned sector during the latter half of the 1990s, as China embarked on a more explicit commitment to institutional convergence with OECD countries. Economic growth since then has occurred largely as a result of de facto privatisation of much of the state sector, and by increasingly laissez-faire regulation of the private sector. This reflected a fundamental transition in the role that the state played in economic development, moving from central planner and enterprise manager to creating the conditions for competition and macroeconomic stability. A key dimension of this has been the adaptation of existing institutions designed for China's planned economy to better fit the requirements for increased market governance. This is in contrast to previous work, which has attributed the rise of the private sector to the existence of informal institutions, in particular 'network-based trust' and guanxi. We propose that guanxi facilitated market-based exchange during the earlier years of the reform period, in the absence of both substantive inter-personal trust and effective formal institutions, but is becoming less important to successful entrepreneurship today. ${ }^{11}$

Our contribution to the literature is three-fold. First, we challenge explanations of private sector emergence that reach into a pre-revolutionary past, in order to propose or assume that recent entrepreneurial activity is a re-emergence of an historical entrepreneurial culture established in Imperial and Republican China. Second, we re-evaluate the development of the conditions for private sector emergence since 1949 by identifying embryonic reforms before the advent of reform in 1978 that assisted the growth of the private sector. We also find that 
conditions for entrepreneurship have been far from conducive during China’s recent reform period, even though much of the emergence of the private sector was stimulated by government policy to liberalise markets. Third, we explain this apparent contradiction through the concept of rule ambiguities that concurrently create entrepreneurial opportunities and make these opportunities fragile and vulnerable to erosion. Rule ambiguities are a by-product of transitional reform, and so have been endemic to China’s recent development.

\section{Rationale}

Why then does this paper warrant and adopt an historical perspective on what appears to be a relatively recent phenomenon? Our response to this is three-fold. Firstly, the recent economic history of China tends to be separated explicitly from events before the formal introduction of the reform period in late 1978. Although this may serve accounts of China that seek to distinguish the politicised era of Maoist China from the more pragmatic and economicallyfocused period of reform introduced by Deng Xiaoping, such a strict time threshold deserves some consideration. Given the political dynamics of China in the 1970s, where leftist proMao officials still held sway over much of the state, adoption of the principles of economic reform in 1978 required negotiation and bargaining to bring onside factions within the Communist Party that needed convincing of the benefits and desirability of reforms. ${ }^{12}$ The mechanism for achieving this was the 'Western Leap Forward', echoing the earlier Great Leap Forward. Deng Xiaoping convincingly made the argument that 'seeking the truth from facts’ was consistent with Maoist orthodoxy, and also allowed for flexibility in reforms, unlike Hua Guofeng’s ‘two whatevers’, which sought to preserve Mao’s thinking. ${ }^{13}$ Much of the two-year period when Hua Guofeng took over as Chairman was taken up with a campaign

to garner formal support for reform within the Communist Party. ${ }^{14}$ Moreover, there were tentative experiments with reform during the early to mid-1970s, as reported by a number of 
commentators on China who argue that the 1978 transition to reform was the culmination of factors and events that preceded this key and public event. ${ }^{15}$

Secondly, the reform era has brought with it social as well as economic liberalisation, which in turn has stimulated reassessments of China's past. Rising interest in China's prerevolutionary cultural traditions, re-exploration of Confucianism as a unifying dimension of Chinese culture, and increased participation in the worship of traditional religions, all point to attempts to re-negotiate contemporary China's relationship with its past. ${ }^{16}$ In China, however, remembering the past is challenging, especially when such accounts consider the country's recent history since 1949 as well as the preceding period. The Mao period was turbulent and remains sensitive to critical analysis, not only because of the periods of national stress and breakdown - the famines and economic collapse of the Great Leap Forward, and the widespread upheaval of the Cultural Revolution - but also because much of the logic of this period was to eradicate the legacies and structures of pre-revolutionary China. ${ }^{17}$ A starting point for this paper, which is fundamental to our analysis of the emergence of the private sector during the reform period, is to consider the effects of China's past on entrepreneurship in contemporary China.

Third, the pace and extent of economic growth and change in China as a result of the emergence of the private sector since 1978 will fundamentally shape the country's future development. In 1978, official statistics indicated that the state sector made up more than 99\% of the economy. ${ }^{18}$ By 2007, the share of GDP by the non-state sector was at least $65 \%$ and by some accounts higher. ${ }^{19}$ As highlighted by Easley, in the period from 1978 to 2004 employment in the private sector went up 300 times and numbers of private enterprises increased at an average rate of 29 per cent a year. ${ }^{20}$ Given the growing proportion of economic activity accounted for by the private sector, the continued development of private 
enterprise is key to future GDP growth. As a result, the extent to which current and future conditions are conducive to entrepreneurship will affect national growth and prosperity.

The motivation for this paper and the basis for framing our research question have been the authors' direct and on-going involvement with private sector development in China since the 1990s. This has arisen from engagement with both government and entrepreneurs, creating a recent historical experience and perspective on private sector development in China. As well as allowing personal insight into the issues covered in this paper over an extended period, this has led to publication of a series of papers on private sector development. These engagements and outputs highlight both the pace of private sector emergence and the complex and changing nature of the relationship between the state and entrepreneurs in China.

By way of situating this paper in the personal histories of individuals wrapped up in these change processes, we offer three brief narratives of specific instances that capture our research question. The first starts in the 'Trade Union Hotel' in an industrial city in China's north in the late 1990s. An internationally educated high-ranking provincial official, charged with the triple challenge of restructuring bankrupt state-owned enterprises (SOEs), transferring ownership of smaller SOEs to non-state entities, and encouraging a then-small private sector to grow in order to employ laid-off workers from the SOEs, acknowledged the importance of the private sector, while at the same time observing that few in government had experience or knowledge of running private enterprises. He recognised the importance of the private sector, but queried the capacity of the government to design and implement interventions to enable its development.

The second plays out in Western China a few years later, in the early 2000s. In a now booming city, the government of which was then peppered with former soldiers holding largely negative views about entrepreneurs, we worked with a municipal official also charged 
with stimulating the private sector in order to generate new jobs for workers laid off from SOEs. He expressed his frustration at having to work with and support local entrepreneurs. In his view, they were making much more money than government officials such as him. Why then should he commit state resources and funding to help these individuals to make more money for themselves?

The third occurs in the second half of the 2000s, during an early evening business dinner in Beijing with a state official from a national government body responsible for SME policy. By this time, private enterprises had come to account for more than half of economic activity, following on from widespread privatisation of smaller SOEs and Township and Village Enterprises. ${ }^{21}$ The government had sought to create an institutional framework to enable private sector development through introduction of the SME Promotion Law. This legislation required municipalities to establish a comprehensive system to stimulate private enterprise development. Despite this, only one city in China, Shenzhen, had created a system of agencies to advise and fund private enterprises. The response by government was to support pilot projects to set up SME support systems in ten cities. At that point, all were still in the pilot stage, and there appeared little confidence that they would deliver the SME support systems envisaged in the original legislation.

Each of these brief narratives highlights the central question of this paper, namely: why did the private sector emerge so successfully in an environment where the institutions, legislation and policies to enable entrepreneurship were lacking?

In order to inform our analysis, we adopt an institutionalist perspective on entrepreneurial emergence in China. Institutional theory, and in particular New Institutional Economics, is increasingly used in the entrepreneurship literature on China and on economic transition. ${ }^{22}$ Institutional theory emphasises the 'rules of the game' of market exchange and broader 
socioeconomic transaction. These can be formal, and they include the legal and market regulation frameworks within which entrepreneurs operate. They can also be informal, emerging from cultural values and socially embedded practices. ${ }^{23}$ The extent to which the institutional 'rules of the game' enable transparent and enforceable market exchange is generally considered essential for entrepreneurs to operate. ${ }^{24}$ The relevance of institutional theory to entrepreneurship in transition economies is increasingly recognised, in large part because many of the key institutions that enable market transactions are in flux in these contexts. $^{25}$

In this paper, we challenge three dimensions of institutional theory as it relates to entrepreneurship in transition economies. Firstly, we present China as a distinctive case of institutional evolution rather than displacement, and so propose that the institutional voids seen in the Former Soviet Union, where institutions from the past were removed and replaced with new institutions, are not a central feature of entrepreneurial emergence in China. This is an important distinction, because theorisations of economic transition have been informed by the experience of the Former Soviet Union, where institutions were dismantled and new institutions introduced, so creating institutional 'voids' for entrepreneurs. ${ }^{26}$ Secondly, we identify changes in institutional frameworks that have occurred over much shorter time periods, decades rather than centuries, than has been proposed in the institutional literature. ${ }^{27}$ Thirdly, and perhaps most importantly, we present reform-era China as a case where entrepreneurship has emerged even though the institutions to enable effective market exchange were not fully established. ${ }^{28}$ 


\section{Institutional change within a broader context of national economic growth in China}

Although an institutional perspective allows for a theoretically consistent consideration of the emergence of entrepreneurship in reform era China, like any theoretical framework its explanatory power and reach has limitations. As such, we recognise that an institutional perspective offers a partial, and hence incomplete, representation of the complexity of economic development and entrepreneurial growth in China since 1978. Recent applications of institutional theory to China confirm this point, noting that institutional development and change is one aspect of economic transition, alongside wider dynamics of market liberalisation and economic reform. ${ }^{29}$ High levels of infrastructure investment throughout the reform period, foreign direct investment, increased international trade, and improvements in factor inputs - in particular educational and human capital effects on labour and technology as a performance enhancer of capital - have been important drivers of wider economic growth. ${ }^{30}$ As a consequence of these wider positive effects of economic growth, the conditions for entrepreneurship to emerge have improved, encouraging entrepreneurs to start and grow private enterprises. ${ }^{31}$

Although these broader dynamics of growth and development exist, and have helped stimulate private sector development, our focus on institutional change and development is justified in two ways. Firstly, there is evidence that the emergence of a private sector of entrepreneurs can be attributed in large part to reforms, and that institutional change made up a large proportion of these reforms. Indeed, one analysis concludes that seven-eighths of the increase in total factor productivity in the reform period was a result of reforms and that institutional change was fundamental to these increases. ${ }^{32}$ Secondly, the standard approach advocated by institutional economists such as Acemoglu and Rodrik does not appear to hold in China, where entrepreneurs have emerged even though the institutions considered necessary for private sector activity have not been in place for much of the reform era. ${ }^{33}$ The 
standard institutional premise is that without effectively functioning market institutions, economic growth through private sector activity will not occur. China therefore represents a particular and distinctive context for institutional change and development that does not align with institutional theorisations of economic development and change in other countries and contexts.

\section{Institutional constraints on entrepreneurship before 1949}

There has been a tendency to identify in China's pre-communist period a 'Confucian tradition [that] created its own version of Adam Smith's moral sentiments', which has since served as a latent foundation for entrepreneurial emergence during the reform period. ${ }^{34}$ However, twentieth-century China before the Chinese Communist Party came to power was economically as well as politically turbulent, with the country experiencing invasion by Japan (occupying Manchuria in 1931), civil war and conflict between the Guomindang and the Communist Party of China from the 1920s, and the emergence of local warlords with little interest in economic development and growth. Where entrepreneurship emerged, such as in Shanghai in the 1920s, this brief 'tradition' disappeared in the economic turbulence of the 1930s. ${ }^{35}$

The Republic, established in 1911 after the death of the last Qing dynasty ruler, Empress

Dowager Cixi, failed to establish control over large parts of China. The final years of Imperial China, before Cixi's death, were economically as well as financially conservative, with little economic reform or opening up, and no emergence of a technocratic elite outside Imperial circles or of effective state entrepreneurship. ${ }^{36}$ This was in clear contrast to Japan during the Meiji Restoration of the second half of the nineteenth century. Attempts to reinforce Confucian values by the Qing dynasty in the second half of the nineteenth century were 
perceived as not credible in either re-asserting these values or the political legitimacy of a declining dynasty. ${ }^{37}$

Society and the economy in late Imperial China and Republican China can be characterised as suffering from weak and, as civil war and conflict emerged, weakening institutions, that undermined the governance of entrepreneurial activity. ${ }^{38}$ As a result, social mechanisms to enable market exchange, such as guanxi and related forms of favour exchange and reciprocity that had emerged in earlier Imperial times were also weakened. ${ }^{39}$ The consequence of this was that, although these institutional forms of interaction continued to exist, and had substantive as well as symbolic importance, their effectiveness and the governance of them eroded as wider economic and political uncertainty emerged in the first half of the twentieth century.

Over a longer period, there is little evidence of a tradition of encouraging entrepreneurship. The values developed during the Qing Dynasty and earlier Imperial rule appear to be more consonant with a Confucian sense of social and economic administration through order and hierarchy than with a developed 'market morality' ${ }^{40}$ The Imperial system centralised, rather than localised, economic as well as political activity, with the state operating as public entrepreneur across much of the Imperial economy: for example, in salt mining and grain transportation through the Grand Canal. This system was predominantly administrative and bureaucratic in nature, built on a system of elevation to official status through passing national examinations, preparation for which focused on legislative and philosophical, rather than commercial, knowledge. The magistrates who operated locally as tax collectors and administrators for the Emperor, in other words, came from a world of regulation rather than a world of commerce. 
The class divisions that characterized the Imperial Era constrained entrepreneurial activity. Under the strict hierarchical social system, based on Neo-Confucian thought, scholars and farmers maintained higher positions in the social strata than artisans and merchants. ${ }^{41}$ Under this system making a profit was seen as unethical, and characteristic of an inferior person. ${ }^{42}$ This discouraged individuals, especially those from the intellectual or landowning classes, from seeking a living through engaging in business. In addition, limited value was placed on the protection of intellectual property during the Imperial Era. Knowledge was seen as something that should be shared widely (a social good), rather than something that could be commoditized and protected under the law. ${ }^{43}$ This proved a disincentive for individuals to innovate, and so served as a constraint on entrepreneurial activity.

As a result, the merchant classes and associated institutions, such as guilds, that developed in Europe were partially formed within a rigid hierarchical system that subordinated merchants. ${ }^{44}$ Economic activities focused on trading, rather than specialisation in crafts-based skills and production, and were organised by identity (geographical or ethnic) of the trading network, rather than by occupation and technical expertise. ${ }^{45}$ Even though a more marketised countryside emerged towards the end of the Imperial Era and into the early years of Republican rule, it did not produce large surpluses and was predominantly focused on the family, undertaking small-scale economic activity concerned mainly with agricultural production and trading. ${ }^{46}$ Where international trade stimulated trading networks, middleman compradors made these activities expensive and inefficient. ${ }^{47}$

Additional factors constraining the industrial development of China over several centuries included: the capacity of rice farming to generate positive, but diminishing, marginal yields that sustained a large rural population; well-developed trade networks that allowed efficient distribution of agricultural outputs, hence 'smoothing out' local variations in harvests; and a 
largely illiterate and innumerate peasant population. Elvin characterised the confluence of these socio-political as well as economic factors as China's 'high-level equilibrium trap', which created disincentives to industrialise in Imperial China and reinforced the predominantly agricultural nature of the economy and hierarchical structure of society. ${ }^{48}$ Indeed, even the economic expansion of late Imperial China suggests a form of high-level equilibrium trap, as such activities enabled maintenance of historic family incomes during a period of population growth, rather than the accumulation of large financial surpluses from agricultural production that are a pre-requisite to industrialisation. ${ }^{49}$

\section{Institutional enablers of - and constraints to - entrepreneurship between 1949 and} 1978

The lack of a stable pre-revolutionary tradition of entrepreneurship raises a major question regarding the economic development of China after 1949: if pre-revolutionary China did not create the conditions and institutions for entrepreneurship, then is it the case that these conditions and institutions emerged during Communist rule, before as well as during the post1978 reform period? Although there is a widely-shared view that the reform era began in December 1978, at the $3^{\text {rd }}$ Plenum of the $11^{\text {th }}$ Chinese Communist Party Congress, some reforms can be traced to earlier in that decade and to the first ten years of Communist rule.

Establishment of a basic healthcare infrastructure in the 1950's - the 'barefoot doctors', who received a minimal level of primary healthcare training, designed to treat simple illnesses and injuries, and introduce preventive methods - radically reduced infant mortality and improved life expectancy in rural areas. ${ }^{50}$ In addition, primary and secondary education was introduced across much of rural China, ensuring basic levels of literacy and numeracy. ${ }^{51}$ As 
well as the positive correlation between primary education and reduced infant mortality found across all developing economies, these two institutional developments produced a large rural workforce that was healthier, more literate, and more numerate. The early to mid-1950s also saw restructuring of China's universities, through merger and the creation of a stronger science and technology base. The expansion of education, from basic to advanced, was a human capital gain that would be exploited three decades later, particularly through rural migration to coastal development zones and major manufacturing centres such as the Pearl River delta. By the mid- to late-1950s, as a result, some of the factor conditions for ensuring the human capital required for future economic growth during the reform period were beginning to emerge.

However, growth was suppressed from the later 1950s to the early 1970s through politicisation of economic activity and a policy of 'self-reliance' that saw China turn in on itself and caused significant damage to the country’s productive capacity. The Great Leap Forward in the second half of the 1950s transformed the centrally planned technocratic approach to industrialisation encouraged by Soviet advisers into a 'backyard' industrial revolution that destroyed agricultural output, created widespread famine and starvation, and severely weakened manufacturing. ${ }^{52}$ The breaking of technical ties with the Soviet Union and, after a brief interregnum, the Cultural Revolution, held back China's economy through most of the 1960s. In the last three years of that decade agricultural and overall economic output fell considerably.

By 1970, the excesses of the Cultural Revolution had played out, and a more politically sensitive order was established, in which economic development was framed in the rhetoric of continued political mobilisation. ${ }^{53}$ Revolutionary Committees at municipal and district level had the power to direct local development based on local conditions and priorities. Previously 
disgraced cadres were rehabilitated. Communes and brigades were used to better organise agricultural production, including recognition of both individual effort and collective output measured by 'work-points'. Productivity and performance increased from 1970 to 1976, with agricultural and total economic output almost doubling, after significant falls between 1967 and $1969 .^{54}$

At the local level, there was investment in commune-based enterprises through this period. A precursor to the township and village enterprises that drove economic growth in the 1980s and 1990s, these ventures were collectively-owned, but in practice were run by individuals operating as entrepreneurial managers, overseen by small groups of local government officials and affiliates at district and commune level. Many of these enterprises had been established in the 1950 s or were legacies of pre-revolutionary capitalism in the countryside. ${ }^{55}$ Typically, the national doctrine of 'self-reliance' meant that enterprises located in more remote places, such as rural Anhui and Sichuan where the agricultural reforms of the early 1980s began, were overlooked during periods of turmoil and political mobilisation.

From 1974 to 1976, with Deng appointed as First Vice Premier, policies were passed to stimulate and recognise economic diversification through 'sideline development', i.e. the encouragement of private and semi-private businesses offering products and services not produced by the state-owned or collective sectors, a theme that was dominant in the early years of the reform period and shaped state policies towards the informal sector and microenterprises. ${ }^{56}$

Economic liberalisation came on the heels of détente and normalisation of relations with the US. As a result of agreements signed by both countries in 1971, there was an influx of Western technology into China, as firstly industrial, and then power generation machinery, was acquired from the US and other countries. ${ }^{57}$ Even the experimental special economic 
zones for foreign investors, a banner policy for Deng in the early 1980s, can be traced back to tentative steps taken by the administration of Hua Guofeng in the mid-1970s. ${ }^{58}$ There was, in other words, a shift towards opening up and experimental reform during the 1970s that preceded the post-1978 reform period.

\section{Institutional adaptation and transformation since 1978}

Unlike the transition economies of the Former Soviet Union, there has been no fundamental change in the economic and political structures of reform-era China. This has created an environment in which institutions established during the period of Maoist central planning have evolved and adapted within an environment of increasing market liberalisation. In this section of the paper, we explore four dimensions of this evolution. First, we consider how the structures of centralised economic control by the Chinese state have adapted and evolved as the priorities of economic reform have developed. Second, we consider the development of quasi-formal contractual arrangements in the absence of private property rights, and how this enabled entrepreneurship in an institutional environment that is not conducive to private sector development. Third, we examine the emergence of local partnerships between government and enterprises to enable economic growth. Finally, we examine the changing nature of guanxi, an institution that enables bilateral exchange through favour trading, and its lessening importance to entrepreneurial success.

\section{Evolution of State Bodies from the Planned to Market Economy}


During the current reform period, the Communist Party has created an institutional context within which markets have been liberalised and private sector competition encouraged, even though many of the entities and institutions involved in, and enabling these changes, were designed to control a planned economy within a Communist political system. These include the five-year planning cycle that continues to direct state expenditure and policy, as well as state organs developed for a centrally controlled state economy. As a result, the Chinese state has maintained the 'enforcement mechanisms' that are a key component of the regulative institutions that are needed to govern economic development. ${ }^{59}$ This has enabled the state to develop a programme of legislation to recognise and support the private sector within an evolving formal institutional framework that has modified itself over time. ${ }^{60}$ Continuity in the formal regulative institutions that have shaped China during its reform period has prevented the 'messiness and chaos of...economic transition' evident in transition economies that have sought to create new market institutions to replace existing institutions developed for a planned economy. ${ }^{61}$

A dynamic of institutional adaptation rather than replacement can be seen in the evolution of key state agencies and the functional roles they have played in economic reform and development. Over the reform period, key agencies established in the pre-reform period have adapted to the new economic landscape of increased market liberalisation, and in doing so have changed themselves as the wider institutions of economic reform have evolved. During the early years of reform, the State Planning Commission (SPC), which was established in the early 1950s to coordinate economic planning, including setting production quotas, oversaw industrial development across national government during the 1980s. As the economy has changed, shifting emphasis from supporting state-owned to collective and then private enterprises, state commissions transformed, adapting their strategic roles to the specific development needs of the period. The SPC and the State Planning Development Commission 
were combined in the early 1990s to establish, initially, the State Economic Commission (SEC), which focused on restructuring of the state-owned sector as the primary emphasis of economic planning during the second half of this decade. The SEC was then transformed into the State Economic and Trade Commission (SETC), reflecting a growing emphasis on economic harmonisation and trade liberalisation as a result of entry into the World Trade Organisation. The SETC has since become the National Development and Reform Commission (NDRC), which increasingly emphasises macro-economic management, reflecting more recent state concerns with economic stability. Over the reform period, each commission absorbed personnel as well as responsibilities from its predecessor(s), re-aligned to the specific development priorities and challenges of particular stages of China's reform period. In this way, key organs of the state adapted to reflect the broader structural changes to the institutional framework that were being pursued at particular stages of reform.

Through ownership transfer to the private sector, the Chinese state has changed its relationship with enterprises, from direct control within a planned production framework to developing an institutional framework and economic conditions that enable and stimulate private sector development. ${ }^{62}$ The continued existence, and incremental evolution, of major policy bodies and the continuation of key policy-making institutions, such as five-year plans and the associated central planning apparatus, provided a sense of continuity and gradual adaption rather than sudden change. From this perspective, China has not experienced the 'voids' that emerged in states undergoing rapid and substantive change to its economic and political institutions, as was the case in the former Soviet Bloc. ${ }^{63}$ Instead, Chinese policy makers have faced a different type of challenge: how to transform institutions designed for a centrally planned economy into ones that enable markets to work efficiently. 
As well as playing a key role in recognising private entrepreneurs as key drivers of economic growth, ${ }^{64}$ the Communist Party created constraints to entrepreneurship during the post-1978 period of reform. The experience of banking institutions through the reform period exemplifies the non-market expectations and requirements placed on key economic institutions. In the early years, standard practices such as effective and objective risk management and credit control were not practised in state-controlled banks, which served as a mechanism for distributing resources to often inefficient state-owned enterprises (SOEs), rather than as an open credit facility. The institutional dysfunctionalities that this created generated huge debt exposures, and effectively 'red-lined' the private sector, which found it difficult to raise capital from state banks. ${ }^{65}$ The rationale for this was both political and social, as the state sought to prop up SOEs that employed a significant proportion of the working urban population.

An institutional preference for state-owned or controlled enterprises is evident for much of the reform period, even after national recognition of entrepreneurs in the early 2000s. In China today private enterprises continue to be discriminated against by the formal financial system. ${ }^{66}$ For example, even though they account for the majority of domestic output, they receive less than $20 \%$ of bank financing. ${ }^{67}$ In addition, equity markets are still immature and have not been effective in allocating resources in the Chinese economy. ${ }^{68}$ In the last decade state-owned enterprises captured around $57 \%$ of the equity from capital markets, leaving a limited proportion to the private sector, especially small and medium-sized enterprises. ${ }^{69}$

A further constraint has arisen because formal regulations are not always upheld consistently, and state sanctions are often applied variably. In many instances, inconsistencies in upholding formal institutions reflect wider political considerations, and decisions: for example, where this relates to political factions and the fortunes of groups or individuals 
within the party. ${ }^{70}$ They also reflect a well-rehearsed tendency for local government to co-opt and adapt national legislation and policy to fit local needs and priorities. ${ }^{71}$

\section{Entrepreneurship without private property rights, but with contracts}

It is a standard tenet of development that private property rights are a necessary condition for sustaining economic growth, since they allow entrepreneurs to retain the surpluses generated from their entrepreneurial activities. ${ }^{72}$ Where property rights do not exist or are ambiguous, the private sector will be constrained, and the capacity for entrepreneurs to generate wealth that in turn stimulates economic growth will be limited. Indeed, the current orthodoxy in international development is that the transfer of private property rights is a pre-condition of income growth through private sector development and without this poverty reduction cannot occur. ${ }^{73}$ In China, however, this proposition has not applied, as entrepreneurship has grown drastically without clear and enforceable formal private property rights. ${ }^{74}$ Through most of the reform period in China there has been no formal legal protection of private ownership rights. ${ }^{75}$ Instead, there were multiple and ambiguous forms of ownership and no clear framework for the governance of private enterprises. A National Property Law that legislated for private ownership was only passed in 2007, and it has since been implemented inconsistently, as can be seen by the continued trend for some officials to expropriate resources and take over control of private enterprises on a periodic and ad hoc basis. ${ }^{76}$

How, then, and why did China's private and non-state sector grow so rapidly during the reform period, given the lack of an enabling institutional framework of formal property rights? One of the major institutional innovations of reform-era China has been the contracting out of state property, creating hybrid forms of enterprise that are publicly owned 
but privately managed. Contracting has been a standard form of managed transition from a planned to a private economy through much of the reform era in China. Under contract-based relationships, the state retains ownership of the asset, whether land or an enterprise, and enters into an agreement to make that asset available to private individuals or entities who take responsibility for output and production. Contracts are drawn up that specify the nature of the charge to be paid to the state for the rights to use the asset productively, as well as its duration and any limits or constraints on its use. The emergence of contracts as a way of preserving state ownership of assets while allowing private exploitation of them enabled expansion of entrepreneurial activity within a state-controlled economy.

\section{Contracting out agricultural production to households (bao chan dao hu) began} spontaneously in rural Anhui province, as a means of breaking out of the productive inefficiencies of collective farming that became the organising logic of agriculture in China between 1952-53 and the early 1980s. ${ }^{77}$ Contracting out agricultural land was formally extended to other provinces after extensive investigation by the central government, and arrangements were extended to include contracting out the plot of land itself, with households signing long-term leases (bao gan dao hu). By 1983, 94\% of rural farming households across China were involving in a form of contracting, having signed annual agreements with their collective or local government that stipulated output targets, inputs and payments to be made. ${ }^{78}$ Households retained resources above and beyond the targets set in these agreements. The result was significant increases in agricultural production through the 1980 s. $^{79}$

Contracting also underpinned the emergence of township and village enterprises (TVEs) in rural areas through the 1980s. TVEs took multiple forms, ranging from private enterprises that operated under the 'red hat' of collective ownership but in practice were private businesses through to enterprises owned by a local township or village government but 
managed by a third party. ${ }^{80}$ Similar contracting arrangements to those in agriculture were established, with 'production’ being contracted out on the basis of several arrangements, including a management fee, retention of surpluses above agreed targets by the manager(s), or profit-sharing arrangements. ${ }^{81}$ The result of this loosening of public control over enterprise management was rapid growth of the TVE sector through the 1980s and into the 1990s. Over this period, contracting strategies were also adopted to transfer the management of lossmaking SOEs into private hands, often as a precursor to sale of the enterprise to the individual or entity holding the contract arrangement for that enterprise.

As state ownership receded, firstly through the transfer of loss-making TVEs into private hands, ${ }^{82}$ and then through the 'release' of smaller, typically loss-making SOEs into private control, contracting arrangements became increasingly redundant. National statistics indicate a significant rise in the private enterprise population in the early 2000s following on from privatisation of both SOEs and TVEs during the 1990 s. ${ }^{83}$ As a result, the relationship between the state and enterprises has changed, from contracting arrangements to transfers of assets to private entrepreneurs. ${ }^{84}$ Contracting, in other words, became an increasingly anachronistic institutional innovation once the state had relinquished many of the assets it would have leased out during the earlier years of reform.

Through contracting, the state created a quasi-formal framework that allowed for some recognition of private management of enterprises. This framework was executed through specific contracts, with no formal legal history of precedents or enforced universal legislation (institutions of central importance to effective legal compliance and hence reduced transaction costs). The possibility of legal redress, should contracts be contravened, provided a limited degree of protection. More importantly, contracts had a symbolic and public significance, signalling an explicit and mutual agreement to let public assets be managed by private hands. 
Protests around expropriation can be seen as reaction to local government breaking an explicit contract, and hence a symbolic commitment to complying with the contract. The notion of contracts, with weaker formal dimensions but stronger symbolic power, provides a more compelling basis for understanding how property rights were negotiated and allocated in China than reference to an 'established folk concept of property rights', ${ }^{85}$ not least because of the weakness of such a folk concept in pre-communist China, as we outlined earlier in this paper.

\section{State pragmatism - government adaptation to enable enterprise development.}

Engagement in contracting highlights one way in which local government has played a central role in economic development through much of the reform period, and in particular until the end of the 1990s, when a 'soft centralisation' was imposed that reduced levels of local autonomy in economic development decision making. ${ }^{86}$ Local governments also adopted pro-development and pro-growth roles across much of China, as 'public entrepreneurs' and in partnership with private enterprises. Local economic development partnerships between the state and private sector emerged as a distinctive institutional feature of many of the areas where growth was greatest in China, especially during the 1980s and 1990s. Examples that have been highlighted have tended to be in areas of economic liberalisation and growth, in particular Guangdong province and many of the Eastern coastal provinces. ${ }^{87}$ However, pro-development local governments can be found in parts of China where foreign investment was minimal. ${ }^{88}$

Local governments encouraged economic growth by supporting and providing investment for private as well as collective and state enterprises. Even where local government focused on friends and family, creating new economic and social hierarchies, investments and 
sponsorship extended beyond the 'feudal relationships' of patronage and nepotism to include strategic investments in growing enterprises regardless of ownership. ${ }^{89}$ These ways of working transcended cronyism, i.e., preferential treatment of family and friends, enabling a wider group of enterprises to grow and contribute to increases in local prosperity. However, state activism has not always been benevolent. Local government intervention in enterprise management has also led to instances of non-productive expropriation of assets and profits, by officials wanting to extract the increased returns generated by these new forms of economic activity. $^{90}$

Over the last 15 years there has been a shift from local pro-growth models of government to national endorsement of the private sector, reflecting rising centralisation of state control. ${ }^{91}$ This has benefitted individual entrepreneurs, who increasingly are endorsed by the Communist Party and state. Publicity campaigns as well as legislation have publicly articulated strong support for the private sector as an important driver of economic growth. Membership of the Communist Party, and its affiliated entities, can be considered a particularly powerful normative institution that provides access to privileges, opportunities and networks that produce positive social and political as well as economic gains. ${ }^{92}$ In a country where there is a strong tradition of top-down messages and campaigns to shape shared values and perceptions, Party sponsorship of private enterprise is likely to be a significant influence on informal cultural-cognitive institutions. ${ }^{93}$

\section{Reassessing network-based trust and guanxi in post-1949 China}

The political and social turbulence of Maoist China undermined many established institutions, as ‘feudal' values were attacked and traditional networks of trust-based relationships dismantled from the outset of Communist Party rule and over much of the three decades after 1949. ${ }^{94}$ Successive political campaigns and mass mobilisation programmes emphasised the 
importance of commitment and loyalty to the Party, which transcended, and displaced, ties with family and kinship groups. Confucian values of hierarchical subordination were directly attacked: for example, through campaigns to create greater equality between men and women, as well as by repeated encouragement of young people to denounce their reactionary elders (a prevalent feature of the Cultural Revolution). Maoist political rhetoric explicitly encouraged the youth to reject their own families and embrace the comradeship of the Chinese Communist Party. ${ }^{95}$

During 1950 and 1951, politicisation of village life, and in particular attacks on 'landlord' peasant families, created social dislocation and strife in the countryside, destroying economic wealth and family enterprises. ${ }^{96}$ Collectivisation in 1952 and 1953 eroded the family unit and local communities, because communes reorganised community life around mass work and living, rather than private kinship units and networks. Collectives remained the basis for agricultural production, and life, through the pre-reform period. Attacks on, and collapses of, family structures were major features of the Great Leap Forward. Erosion of the family unit was compounded when Red Guards first left their homes in the late 1960s and then were 'sent down' to the countryside in the 1970s, many not returning to their urban homes until late in that decade or early in the 1980s. Widespread mobilisation of rural peasants on major infrastructure projects split families and displaced people from their traditional homes.

Conditions such as these were unpropitious for sustaining local networks. In a highly politicised environment, where loyalty to Mao and the Party was prized above personal relations, trust often broke down as members of the same family, kinship group or local community competed to demonstrate political loyalty. The post-Mao literature on the Cultural Revolution provides accounts of children denouncing their parents to preserve their record of political commitment. ${ }^{97}$ Under these circumstances, network-based trust was traded for wider 
socio-political recognition, often acquired through public rejection of emotional, kinship and community loyalties.

Politicisation of society, and public attacks on hereditary ties, created the conditions for traditional loyalties and associations to be eroded and replaced with the new 'family' of party comradeship. ${ }^{98}$ The scale of this mobilisation, and the massive changes these dynamics created, should not be underestimated. Standard institutional theories propose that informal institutions such as customs, traditions, norms and beliefs change over centuries, based on the assumption that 'informal institutions have mainly spontaneous origins - which is to say that deliberative choice of a calculative kind is minimally implicated' ${ }^{99}$ In post-1949 China, however, successive calculated changes to institutions were initiated by the Party, starting in the early 1950s with the appropriation of farmland from landowners, and followed rapidly by collectivisation of agricultural production. Major institutional changes resulted in social and economic turbulence, and, in the case of the Great Leap Forward, breakdown. Dikotter describes in great detail the mass starvation, and resultant collapse of social structures and societal norms and values that occurred as a result of the failure of the Great Leap Forward to generate sustainable and productive industrial growth. ${ }^{100}$ In particular, the notion of the family and community was eradicated in many areas, when children were first taken away from their mothers, who were then 'liberated' to work, and then made to work themselves, often in dangerous conditions, ${ }^{101}$ the elderly were abandoned, left to starve by their families and communities, ${ }^{102}$ and individuals resisted the collective through shirking, ${ }^{103}$ theft and fraud. $^{104}$

The scale, pace and turbulence of political mobilisation to attack and remove traditional informal institutions through the 1950s, 1960s and 1970s, combined with the institutional flux and political uncertainty that characterised China before the Communists came to power in 
1949, suggest that networks of trust and traditional Confucian values of kinship and community affiliation would have been eroded by the advent of economic reform in the late 1970s. As a result, a case can be made that network-based trust has been severely undermined in Communist China, and that local and particularistic loyalties that arose from substantive rather than formal rationalities were attacked during the Maoist period. As Vogel noted, dedication to Maoism as a value system, and to Mao as a figurehead, replaced personal relationships. This resulted in individuals committing to the Western universalism of the communist state, in which many Chinese citizens placed great trust (both genuinely and as an expedient means of survival and personal advancement). ${ }^{105}$

Trust based on traditional kinship and community networks is evident in contemporary China in the exception rather than the norm, supporting the notion that broader societal trust eroded after 1949. Wenzhou, for example, which has been recognised as one of the entrepreneurial ‘success stories’ of China, is distinctive not only because of its economic dynamism but also because it has a strong local culture of entrepreneurship underpinned by a sense of local community informed by mistrust of the state and 'outsiders'. ${ }^{106}$ Such 'traditional' values are also evident in minority ethnicities, which have been largely marginalised in contemporary China. In cases such as these, trust-based networks are defensive, rather than enabling, in that they offer a means of mobilising scarce resources and defending the group against the interests and incursions of others.

The erosion of network-based trust in Communist China helps in part to explain why symbolic demonstrations and rituals of reciprocal gift and favour exchange have been important during the period of reform, especially during its early years. In a culture where traditional kinship and community foundations for group trust have been systematically eroded by a politicised state, gift exchange and the trading of like-for-like favours offers an 
explicit and hence more enforceable semi-formal ‘currency’ for governing exchange. The benefits of favour exchange to regulate trading and commerce were higher at the outset of the reform period, when the institutional mechanisms for governing market exchange were emerging rapidly, and so were unclear and subject to change.

The institutional 'rules of the game' for increasingly liberalised market exchange were underdeveloped in the early reform period, with prices continuing to be distorted as a result of the parallel system of dual pricing (both state-controlled and market-determined), thus creating ambiguity around trading mechanisms and protocols. This placed increased emphasis on building new forms of trust relationships and governance mechanisms in an institutional context where markets were partially formed and enforcement mechanisms unclear.

Reciprocal exchange routines, such as gift giving and the exchange of favours through guanxi arrangements, helped develop personalised forms of negotiated and bartered trust, and hence bilateral governance frameworks for exchange. ${ }^{107}$ In a context where market trading was new and unfamiliar to many, reciprocity signalled commitment to the exchange, thereby offering a loose governance framework, albeit one that could be difficult to enforce should one party renege on the agreement.

The nature of guanxi, and its role in market transactions, has since changed considerably. Reconsiderations of guanxi emphasise its inherently adaptive and malleable nature, and in doing so challenge notions of it as a 'fixed' or 'essential' dynamic, and hence a traditional institution within Chinese society. ${ }^{108}$ Whereas some reconsiderations of guanxi argued for its persistence as an evolving institution, there is debate as to its continuing importance in enabling market exchange. Guthrie noted the declining importance of personalised guanxi during this period. ${ }^{109}$ More recent empirical analysis supports this view of the declining significance of guanxi for the economic growth of private enterprises, with studies providing 
evidence that guanxi, while still important, is not as significant as management and organisational competence to entrepreneurial success in China. ${ }^{110}$

\section{Conclusion: Rule ambiguities for entrepreneurs in reform-era China}

This paper has explored the emergence of a dynamic private sector in China during a period when many of the formal institutions that enable entrepreneurship were lacking. The evidence does not support a pre-Communist entrepreneurial tradition that has been re-discovered during the current reform period. Moreover, the conditions for economic growth can be traced in part to institutional developments and reforms in the 1950s and early to mid-1970s, as well as to reforms introduced since 1978.

Institutional innovations specific to China, in particular, adaptation of existing institutions designed for a planned economy, alongside widespread use of contracting to deal with ownership issues, and pervasive local experimentation and adaptation, created 'bottom-up', emergent and hence quasi-formal institutional frameworks that enabled localised entrepreneurial emergence, despite a national framework that privileged state-owned over private enterprises. More recent institutional developments have increasingly emphasised convergence with the developed OECD nations, thereby further modifying earlier institutional arrangements.

China's economic growth during the post-1978 reform period, in other words, has been based on adaptation rather than creation of institutions to enable governance of market exchange. The often improvised and reactive nature of institutional adaptation has prevented a single coherent pattern of economic reform, and has generated a wider economic context of evolution rather than displacement of institutions. As a result, the 'voids' evident in the 
transition economies of the Former Soviet Union, which arose as the institutions of economic planning were removed and market institutions created, are neither readily apparent nor pervasive during China’s recent period of economic reform. Instead, institutions have evolved and agencies and policies modified to ensure institutional arrangements align with emerging forms of economic activity and organisation. ${ }^{111}$

Adaptation of institutions and their related agencies and mechanisms to evolving economic structures has created what may be termed 'rule ambiguity' in market exchange and governance. Rule ambiguities arise when changing institutional arrangements alter the 'rules of the game', which as a result are in flux and not stable. Changes in the institutional rules of the game create ambiguity, because they create conditions where the nature and quality of information is uncertain and so entrepreneurs cannot use this information to make effective decisions. ${ }^{112}$ Ambiguity is defined as 'uncertainty about [the] probability' that the information will produce expected results and outcomes. ${ }^{113}$ Uncertainty about the changing nature of these rules creates institutional ambiguities, in the sense that while they are occurring, these changes make market transactions less predictable. In other words, rule ambiguities arise when there is uncertainty about the quality of information relating to a transaction.

In these circumstances, which have been typical of China during the reform period, the institutional rules that govern exchange - both formal and informal - are not fixed and the norms for market activity as a result are not agreed or codified. Such an environment generates opportunities that entrepreneurs exploit, in that rule ambiguities create mismatches between demand and supply as well as information asymmetries, which in turn become rents that an entrepreneur can exploit as long as these ambiguities persist. ${ }^{114}$ The persistence of rule ambiguities provides an explanation as to why the private sector has expanded while the 
institutions of a market economy were not developed and the institutions of a transition economy were mutating and evolving.

Opportunity-creating rule ambiguities also create challenges for entrepreneurs, who cannot be confident of the transaction costs of market exchange or the extent to which such exchanges are enforced. Under conditions of rule ambiguity, there may not be an agreed and consistent basis on which private enterprises can continue to exploit opportunities. Unclear and changing relationships between business and government can lead to dysfunctional behaviours by the state, ranging from lack of support for the private sector through to expropriation of assets and resources. ${ }^{115}$ As a result, entrepreneurs take on the risk that rule ambiguities could lead to expropriation of surpluses or summary termination of an exploited market opportunity by the state. In a context of on-going rule ambiguity, the deployment of personal relationships and reciprocal favour exchange, mediated through guanxi arrangements, provide personalised measures for managing risk and uncertainty in economic exchange. However, they do not constitute a clear and enforceable legal framework or a public regime of formal and informal sanctions that punish avoidance, cheating or dishonesty. Instead, they create a transaction-specific arrangement reached by mutual negotiation, rather than through a normalised governance framework, and so are vulnerable to abuse or termination. The nature of these guanxi arrangements therefore can generate the adverse effects from rule ambiguities that these arrangements were seeking to mitigate.

The notion of rule ambiguities highlights a central paradox of the reform era in China. Rule ambiguities create mismatches between demand and supply, often as a result of information asymmetries between consumer and seller. These mismatches create market opportunities for entrepreneurs who are able to exploit these market imperfections. In a transition economy where rule ambiguities persist over time, as institutions evolve, profits from market 
imperfections are likely to hold for longer than in economies where market institutions enable efficient transmission and sharing of information. Rule ambiguities, in other words, generate entrepreneurial rents than can be durable over considerable periods in countries such as China, whereas in more mature market economies these rents would quickly disappear through efficient information flows.

However, rule ambiguities make the transactional environment of the entrepreneur challenging, and increase the vulnerability of private enterprises not protected by the public patronage enjoyed by state- and collectively-owned enterprises. For private enterprises without such patronage, there is no assurance of recourse to arbitrating institutions, such as a commercial law system that is complied with, and there is reduced scope to secure intervention by the state in their favour. Rule ambiguities therefore create entrepreneurial opportunity, but they also undermine safe, secure and predictable economic transactions, hence making opportunity exploitation risky and vulnerable. This paradox can be seen anecdotally in China, where many individuals set up businesses after having identified opportunities, but are then unable to sustain them because of institutional ambiguities that fail to effectively govern these opportunities.

Although rule ambiguities are evident, there are cases where institutional clarifications are slowly addressing these transactional frailties in market exchange. The 2007 National Property Law is a case in point. Whereas such legislation was not acceptable to the Communist Party and state in the 1990s, its endorsement in the 2000s created a clearer institutional foundation for protecting the surpluses generated by private entrepreneurs. However, wide-scale non-compliance and a fragile legal system make redress under this legislation challenging and generally difficult to secure. ${ }^{116}$ Rule ambiguities persist, in other 
words, and are being addressed as the legal system is being strengthened as a means of seeking formal redress for violations of law. ${ }^{117}$

As has been noted earlier in this paper, the dynamics of institutional change and evolution, and the rule ambiguities this generates, have occurred within a broader context of macroeconomic growth through market liberalisation and enhancement of factor inputs, in particular technology and human capital, as well as investment and intervention by the state. These wider growth effects have stimulated rising demand from consumers and businesses as well as driving improved performance of firms and improved efficiencies in their management. Within this context, dynamics of institutional change have had an important effect on private sector emergence and development. However, broader dynamics of economic growth have also had a fundamentally positive impact on entrepreneurial activity. Combined with the institutions that emerged in reform era China, which are particular to that context, wider growth effects also helped entrepreneurship to emerge when many market institutions were under-developed. Our analysis indicates that without institutional developments that sought to respond to the specific growth challenges at different points in the reform period - such as the emergence of hybrid entrepreneurship and the widespread use of contracts in place of private ownership - the conditions for entrepreneurial emergence would not have been as conducive, even within this broader context of rapid economic growth. 


\section{References}

Acemoglu, D., S. Johnson, and J. Robinson. 'Institutions as a Fundamental Cause of Long-Run Growth’. Handbook of Economic Growth. Amsterdam: Elsevier.

Ahlstrom, D., and G. Bruton. 'Venture Capital in Emerging Economies: Networks and Institutional Change.’ Entrepreneurship Theory \& Practice 30 (2006): 299-320.

Allen, F., J. Qian., C. Zhang., and M. Zhao. China's Financial System: Opportunities and Challenges. National Bureau of Economic Research Working Paper No. 17828. Cambridge, MA: National Bureau of Economic Research, 2012.

Anderson, A., J. Li, R. Harrison, and P. Robson. 'The Increasing Role of Small Business in the Chinese Economy.' Journal of Small Business Management 41 (2003): 310-16.

Arthur, B. 'Competing Technologies, Increasing Returns, and Lock-In by Historical Events'. The Economic Journal 99 (1989): 116-31.

Arthur, B. Increasing Returns and Path Dependence in the Economy. Michigan: University of Michigan Press, 1994.

Ash, R. 'The Evolution of Agricultural Policy.’ The China Quarterly 116 (1988): 52955.

Atherton, A. 'From "Fat Pigs" and "Red Hats” to a "New Social Stratum”. The Changing Face of Enterprise Development Policy in China.' Journal of Small Business and Enterprise Development 15 (2008): 640-55. 
Atherton, A., and D. Smallbone. 'Promoting Private Sector Development in China: The Challenge of Building Institutional Capacity at the Local Level.’ Environment and Planning C 31 (2013): 5-23.

Atherton, A., and D. Smallbone. 'State Promotion of SME Development at the Local Level in China. An Examination of Two Cases.' Journal of Chinese Entrepreneurship 2 (2010): 225-41.

Baumol, W. 'Entrepreneurship: Productive, Unproductive, and Destructive.' Journal of Business Venturing 11 (1996): 3-22.

Bickers, R. The Scramble for China. Foreign Devils in the Qing Empire, 1832-1914. London: Allen Lane/Penguin, 2010.

Blecher, M., and V. Shue. Tethered Deer: Government and Economy in a Chinese County. Stanford, Stanford University Press, 1996.

Breznitz, D. and M. Murphree. Run of the Red Queen: Government, Innovation, Globalization, and Economic Growth in China. New Haven: Yale University Press.

Broughton, E., and D. Walker. 'Policies and Practices for Aquaculture Food Safety in China.’ Food Policy 25 (2010): 471-78.

Camerer, C., and M. Weber. 'Recent developments in modelling preferences: uncertainty and ambiguity.' Journal of Risk and Uncertainty 5 (1992): 325-70.

Chan, K. ‘Turning Point in China’s Comprador System: Kma's Changing Marketing Structure in the Lower Yangzi Region, 1912-25.’ Business History 43 (2001): 51-72. Chang, J. Wild Swans. New York: Harper, 2004 
Chen, W.H. 'Does the Colour of the Cat Matter? The Red Hat Strategy in China's Private Enterprises.' Management and Organization Review 3 (2007): 55-80.

Chen, B., and Y. Feng. 'Determinants of Economic Growth in China: Private Enterprise, Education, and Openness.' China Economic Review 11 (2000): 1-15.

Chen, B., and S. Rozelle. 'Leaders, Managers, and the Organization of Township and Village Enterprises in China.’ Journal of Development Economics 60 (1999): 529-57.

Chen, Z., Sun, Y., Newman, A. and W. Xu. 'Entrepreneurs, Organizational Members, Political Participation and Preferential Treatment: Evidence from China.’ International Small Business Journal 30 (2012): 873-89.

Cheng, N. Life and Death in Shanghai. New York: Flamingo, 1995.

Chow, G. China's Economic Transformation. Malden, MA: Blackwell Publishing, 2002.

Chow, G. Understanding China’s Economy. World Scientific: Singapore, 1994

David, P. 'Why are Institutions the "Carriers of History”? Path Dependence and the Evolution of Conventions, Organizations and Institutions.' Structural Change and Economic Dynamics 5 (1994): 205-20.

De Soto, H. The Mystery of Capital. New York: Basic Books, 2000.

De Soto, H. The Other Path. New York: Basic Books, 1989.

Demurger, S. 'Infrastructure Development and Economic Growth: An Explanation for Regional Disparities in China?’ Journal of Comparative Economics 29(2001): 95-117.

Demsetz, H. 'Toward a Theory of Property Rights.' American Economic Review 57 (1967): 347-59. 
Dickson, B. Red Capitalists in China: the Party, Private Entrepreneurs, and Prospects for Political Change. Cambridge: Cambridge University Press, 2003.

Didier, T., and S. Schmukler. The Financing and Growth of Firms in China and India. Evidence from Capital Markets. Policy Research Working Paper No. 6401. Washington, DC: The World Bank, 2013.

Dikotter, F. The Tragedy of Liberation: A History of the Chinese Revolution 1945-1957. London: Bloomsbury, 2013.

Dikotter, F. Mao’s Great Famine: The History of China’s Most Devastating Catastrophe, 1958-1962. London: Bloomsbury, 2010.

Ding, S., Guariglia, A. and J. Knight. 'Investment and Financial Constraints in China: Does Working Capital Management Make a Difference?’ Journal of Banking and Finance, 37 (2013): 1490-1507.

Dotson, J. The Confucian Revival in the Propaganda Narratives of the Chinese Government. US-China Economic and Security Review Commission Staff Research Report, 2011.

Eesley, C. Entrepreneurship and China: History of Policy Reforms and Institutional Development. Stanford, CA: Stanford University, 2009.

Elvin, M. The Pattern of the Chinese Past. Stanford, CA: Stanford University Press, 1973.

Epstein, L., and M. Schneider. 'Ambiguity, Information Quality, and Asset Pricing.' Journal of Finance 63 (2008): 197-228 
Fagan, M., and S. Zhao. 'SME Financing in China: The Current Situation, Problems and Possible Solutions.' International Journal of Entrepreneurship and Small Business, 8 (2009): 171-85.

Fairbank, F. China: A New History. Cambridge, MA: Harvard University Press, 1992.

Feuerwerker, A. 'The State and the Economy in Late Imperial China.' Theory and Society 13 (1984): 297-326.

Gardella, R. 'Squaring Accounts: Commercial Bookkeeping Methods and Capitalist Rationalism in Late Qing and Republican China.' The Journal of Asian Studies 51 (1992): 317-39

Garnaut, R., and L. Song. 'Impact and Significance of State-Owned Restructuring in China.' China Journal 55 (2006): 35-63.

Gittings, J. The Changing Face of China. From Mao to Market. Oxford: Oxford University Press, 2006.

Guthrie, D. 'The Declining Significance of Guanxi in China’s Economic Transition.’ China Quarterly 154 (1998): 254-82.

Hamilton, G. 'The Organizational Foundations of Western and Chinese Commerce: A Historical and Comparative Analysis'. In Asian Business Networks, edited by G. Hamilton. Berlin: de Gruyter, 1996.

He, X. 'The Development of Entrepreneurship and Private Enterprise in the People’s Republic of China and Its Relevance to Transitional Economies.' Journal of Developmental Entrepreneurship 14 (2009): 39-58. 
He, X., and X. Li. 'Entrepreneurial Competence and Enterprises’ Growth: An Empirical Study in China.’ Economic Research Journal (jingji yanjiu) October (2005): 101-11.

Heilman, S. 'Policy Experimentation in China’s Economic Rise’ Studies in Comparative International Development 43 (2008): 1-6.

Henisz, W. 'The Institutional Environment for Economic Growth.’ Economics and Politics 12 (2000): 1-31.

Hughes, N. China's Economic Challenge: Smashing the Iron Rice Bowl. New York, NY: Eastgate Books, 2002.

Jefferson, G., and J. Siu. 'Privatization and restructuring in China: Evidence from shareholding ownership, 1995-2001.’ Journal of Comparative Economics 34 (2006): 14666.

Keefer, P. 'Governance and Economic Growth in China and India'. In Dancing With Giants, edited by A. Winters, and S. Yusuf. Washington, DC: World Bank, 2007.

Khanna, T., Palepu, K. and J. Sinha. 'Strategies that Fit Emerging Markets.' Harvard Business Review 83 (2005: 63-76.

Khanna, T., and K. Palepu. 'Why Focused Strategies May be Wrong for Emerging Markets.’ Harvard Business Review 75 (2005): 41-51.

Kielsgard, M., and L. Chen. 'The Emergence of Private Property Law in China and Its Impact on Human Rights’. Available: http://works.bepress.com/mark_kielsgard/1, Accessed on 16 May 2014. 
Kirzner, I. 'Entrepreneurial Discovery and the Competitive Market Process: An Austrian Approach.’ Journal of Economic Literature 35 (1997): 60-85.

Lampton, D.M. 'Performance and the Chinese Political System: A Preliminary Assessment of Education and Health Policies.' China Quarterly 75 (1978): 509-39.

Lehman, J.A. 'Intellectual Property Rights and Chinese Tradition Section: Philosophical Foundations.' Journal of Business Ethics 69 (2006): 1-9.

Lewis, A. 'Economic Development with Unlimited Supplies of Labour.' Manchester School of Economics and Social Studies 22 (1954): 139-91.

Li, V.H. 'Politics and Health Care in China: The Barefoot Doctors.' Stanford Law Review 27 (1975): 827-40.

Li, H., and S. Rozelle. 'Privatizing Rural China: Insider Privatization, Innovative Contracts and the Performance of Township Enterprises.' China Quarterly 176 (2003): 981-1005.

Lin, J.Y. 'The Needham Puzzle: Why the Industrial Revolution Did Not Originate in China.' Economic Development and Cultural Change 43 (1995): 269-92.

Liu, X., Burridge, P. and P. Sinclair. 'Relationships Between Economic Growth, Foreign Direct Investment and Trade: Evidence from China’. Applied Economics 34(2002): 14331440.

Liu, Y. 'Revisiting Hanyeping Company (1889-1908): A Case Study of China’s Early Industrialisation and Corporate History.' Business History 52 (2010): 62-73. 
Liu, Y.L. 'Reform From Below: The Private Economy and Local Politics in the Rural Industrialization of Wenzhou.' China Quarterly 130 (1992): 293-316.

Long, C.X. 'Does the Rights Hypothesis Apply to China?’ Journal of Law and Economics 53 (2010): 629-50.

McMullin, J. 'Comments: Do Chinese Environmental Laws Work? A Study of Litigation as a Response to the Problem of Fishery Pollution.' UCLA Pacific Basin Law Journal 26 (2009): 142.

Ma, X., Yao, Y. and Y. Xi. 'Business Group Affiliation and Firm Performance in a Transition Economy: A Focus on Ownership Voids.' Asia Pacific Journal of Management 23 (2006): 467-83.

Maddison, A. 'Measuring the Economic Performance of Transition Economies: Some Lessons from Chinese Experience.’ Review of Income and Wealth 55 (2009): 423-41.

Maddison, A. Chinese Economic Performance in the Long Run. Paris: OECD, 2008.

Mertha, A. 'Fragmented Authoritarianism 2.0: Political Pluralisation in the Chinese Policy Process.' China Quarterly 200 (2009): 995-1012.

Mertha, A. 'China’s “Soft” Centralization: Shifting Tiao/Kuai Authority Relations.' China Quarterly 184 (2005): 791-810.

Murrell, P. 'Evolutionary and Radical Approaches to Economic Reform.' Economics of Planning 25 (1992): 79-95.

Myers, R. 'How Did the Modern Chinese Economy Develop? - A Review Article.' The Journal of Asian Studies 50 (1991): 604-28. 
Nolan, P. 'China and the Global Business Revolution.' Cambridge Journal of Economics 26 (2002): 119-37.

Nolan, P., and F. Dong. Market Forces in China: Competition and Small Business - The Wenzhou Debate. London: Zed Books, 1990.

Nolan, P., and S. Paine. 'Towards an Appraisal of the Impact of Rural Reform in China 1978-85.' Cambridge Journal of Economics 10 (1986): 83-99.

North, D. Institutions, Institutional Change and Economic Performance. Cambridge: Cambridge University Press, 1990.

North, D. 'Institutions.’ Journal of Economic Perspectives 5 (1991): 97-112.

North, D. 'Economic Performance through Time.’ American Economic Review 84 (1994): 359-68.

North, D. 'Epilogue: Economic Performance Through Time’. In Empirical Studies in Institutional Change, edited by L. Alston, T. Eggertsson, and D. North. Cambridge: Cambridge University Press, 1996.

North, D. Understanding the Process of Economic Change. Princeton, NJ: Princeton University Press, 2005.

North, D. and R. Thomas. 'An Economic Theory of the Growth of the Western World.' Economic History Review 23 (1970): 1-17.

North, D. and R. Thomas. The Rise of the Western World. A New Economic History. Cambridge: Cambridge University Press, 1973. 
North, D. and B. Weingast. 'The Evolution of Modern Institutions of Growth'. In Empirical Studies in Institutional Change, edited by L. Alston, T. Eggertsson, and D. North. Cambridge: Cambridge University Press, 1996.

Oi, J. State and Peasant in Contemporary China. Berkeley, CA: University of California Press, 1989.

Oi, J. 'The Role of the State in China’s Transition Economy.' China Quarterly 144 (1995): 1132-49.

Oi, J. Rural China Takes Off: Institutional Foundations of Economic Reform. Berkeley, CA: University of California Press, 1999.

Oi, J. 'Two Decades of Rural Reform in China: An Overview and Assessment.' China Quarterly 159 (1999): 616-28.

Pan, P. Out of Mao's Shadow. The Struggle for the New China. New York, NY: Picador, 2008.

Peng, M., and J. Zhou. 'How Network Strategies and Institutional Transitions Evolve in Asia.’ Asia Pacific Journal of Management 22 (2005): 321-36.

Polishchuck, L. 'Missed Markets: Implications for Economic Behaviour and Institutional Change.' In Transforming Post-Communist Political Economies, edited by J. Nelson, C. Tilly, and L. Walker. Washington, DC: World Bank, 1997.

Przeworski, A., and F. Limongi. 'Political Regimes and Economic Growth.’ Journal of Economic Perspectives 7 (1973): 51-69. 
Puffer, S., McCarthy, P., and M. Boisot. 'Entrepreneurship in Russia and China: The Impact of Formal Institutional Voids.' Entrepreneurship Theory \& Practice 34 (2009): 441-67.

Ranis, G., and J. Fei. 'A Theory of Economic Development.' The American Economic Review 51 (1961): 533-65.

Rodrik, D. 'Goodbye Washington Consensus, Hello Washington Confusion? A Review of the World Bank's Economic Growth in the 1990s: Learning from a Decade of Reform.' Journal of Economic Literature 64 (2006): 973-987.

Rodrik, D., A. Subramanian, and F. Trebbi 'Institutions Rule: The Primacy of Institutions Over Geography and Integration in Economic Development’. Journal of Economic Growth 9(2004): 131-165.

Rodrik, D. 'Institutions for High-Quality Growth: What They Are and How to Acquire Them.' Studies in Comparative International Development 35 (2000): 3-31.

Ruf, G.A. Cadres and Kin. Stanford, CA: Stanford University Press, 1998.

Sachs, J. ‘The Transition at Mid Decade.' The American Economic Review 86 (1996): 128-33.

Sachs, J., W.T., Woo, S. Fischer, and G. Hughes. 'Structural Factors in the Economic Reforms of China, Eastern Europe, and the Former Soviet Union.' Economic Policy 9 (1994): 101-45. 
Sautet, F. 'The Role of Institutions in Entrepreneurship: Implications for Development Policy.’ Mercatus Policy Primer Social Science Research Network: http://papers.ssrn.com/sol3/papers.cfm?abstract_id=1264033, accessed on 16 ${ }^{\text {th }}$ May 2014.

Schram, S. ““Economics in Command”: Ideology and Policy Since the Third Plenum.' China Quarterly 99 (1984): 417-461.

Scott, W. Institutions and Organizations. Ideas and Interest. Thousand Oaks, CA: Sage, 1995.

Scully, G. 'The Institutional Framework and Economic Development.' Journal of Political Economy 96 (1988): 652-62.

Siu, H. Agents and Victims in South China: Accomplices in Rural Revolution. New Haven, CT: Yale University Press, 1989.

Skinner, W. 'Chinese Peasants and the Closed Community: An Open and Shut Case.' Comparative Studies in Society and History 13 (1971): 270-81.

Smallbone, D., and F. Welter. Entrepreneurship and Small Business Development in Post Socialist Economies. London: Routledge, 2009.

Song, M. ‘A Dissonance in Mao’s Revolution: Chinese Agricultural Imports from the United States, 1972-1978.’ Diplomatic History Published online June 7, 2013.

Stone, C.R. 'What Plagiarism Was Not: Some Preliminary Observations on Classical Chinese Attitudes Toward What the West Calls Intellectual Property.' Marquette Law Review 92 (2008): 199-230. 
Tan, J., and D. Tan. 'Environment-Strategy Co-Evolution and Co-Alignment: A Staged Model of Chinese SOEs under Transition.' Strategic Management Journal 26 (2005): 14157.

Teiwes, F., and Sun, W. 'China’s Economic Reorientation After the Third Plenum: Conflict Surrounding “Chen Yun’s” Readjustment Program.' China Journal 70 (2013): 163-187.

Teiwes, F., and Sun, W. 'China’s New Economic Policy Under Hua Guofeng: Party Consensus and Party Myths.' China Journal 66 (2011): 1-23.

ten Brink, T. 'Perspectives on the Development of the Private Business Sector in China.' China: An International Journal 10 (2012): 1-19

Tenev, S. 'Why China Grows from Below.' Far Eastern Economic Review 169 (2006): 22-5.

The Economist. Bamboo Capitalism. London: The Economist, 2011.

Tsai, K. Capitalism Without Democracy. The Private Sector in Contemporary China. Ithaca, NY: Cornell University Press, 2007.

Tsai, K. Back-Alley Banking. Private Entrepreneurs in China. Ithaca, NY: Cornell University Press, 2002.

Unger, J., and A. Chan. 'Inheritors of the Boom: Private Enterprise and the Role of Local Government in a Rural South China Township.' China Journal 42 (1999): 45-74.

Vogel, E. 'From Friendship to Comradeship: The Change in Personal Relations in Communist China.' The China Quarterly 21 (1965): 46-60. 
Wang, H. The End of the Revolution. China and the Limits of Modernity. London: Verso, 2009.

Wang, R. ‘The Rise of Political Confucianism in Contemporary China.’ In The Renaissance of Confucianism in Contemporary China, edited by R. Fan. Philosophical Studies in Contemporary Culture 20 (2011): 33-45.

Weatherall, R. Mao's Forgotten Successor: The Political Career of Hua Guofeng. Basingstoke: Palgrave MacMillan, 2010.

Weitzman, M., and C.G. Xu. Chinese Township Village Enterprises as Vaguely Defined Cooperatives. 155. London: Centre for Economic Performance, London School of Economics and Political Science, 1993.

Whyte, M.K. 'The Social Roots of China’s Economic Development.' China Quarterly 144 (1995): 999-1019.

Williamson, O. 'The New Institutional Economics: Taking Stock, Looking Ahead.' Journal of Economic Literature 38 (2000): 595-613.

World Bank. World Development Report 2009. Washington, DC: World Bank, 2008.

Xu, C. 'The Fundamental Institutions of China's Reform and Development.' Journal of Economic Literature 49 (2011): 1076-1151.

Yan, Y. The Flow of Gifts. Reciprocity and Social Networks in a Chinese Village. Stanford, CA: Stanford University Press, 1996.

Yang, K. Entrepreneurship in China. Farnham: Ashgate, 2007. 
Yang, K. 'Institutional Holes and Entrepreneurship in China.' The Sociological Review 52 (2004): 371-89

Yang, K. ‘Double Entrepreneurship in China’s Economic Reform: An Analytical Framework.' Journal of Political and Military Sociology 30 (2002): 134-47.

Yang, M. 'The Resilience of Guanxi and Its New Deployments: A Critique of Some New Guanxi Scholarship.’ China Quarterly 170 (2002): 459-76.

Yang, M. 'The Gift Economy and State Power in China.' Comparative Studies in Society and History 31 (1989): 25-54.

Yeh, W. Shanghai Splendour: Economic Sentiments and the Making of Modern China. Berkeley, CA: California University Press, 2007.

Yueh, L. 'What Drives China’s Growth?’ National Institute Economic Review 223(2013): 4-15.

Zhao, Z. Prisoner of the State. The Secret Journal of Chinese Premier Zhao Ziyang. Translated and edited P. Bao, R. Chiang, and A. Ignatius. London: Pocket Books, 2010.

\section{Notes}

${ }^{1}$ Rodrik, 'Institutions for High Quality Growth'.

${ }^{2}$ Arthur, ‘Competing Technologies, Increasing Returns, and Lock-In by Historical Events’; Arthur, Increasing Returns and Path Dependence in the Economy; David, 'Why are Institutions the “Carriers of History”? Path Dependence and the Evolution of Conventions, Organizations and 
Institutions’; North, Institutions, Institutional Change and Economic Performance; North, 'Institutions’; North, ‘Economic Performance through Time’; North, Understanding the Process of Economic Change. Williamson, ‘The New Institutional Economics: Taking Stock, Looking Ahead'. Anderson et al., 'The Increasing Role of Small Business in the Chinese Economy'; Chen and Feng, 'Determinants of Economic Growth in China: Private Enterprise, Education, and Openness'; Garnaut and Song, 'Impact and Significance of State-Owned Restructuring in China'; He, 'The Development of Entrepreneurship and Private Enterprise in the People’s Republic of China and Its Relevance to Transitional Economies’; Hughes, China’s Economic Challenge: Smashing the Iron Rice Bowl; Tan and Tan, 'Environment-Strategy Co-Evolution and CoAlignment: A Staged Model of Chinese SOEs under Transition; Tenev, 'Why China Grows from Below'.

${ }^{3}$ Demsetz, 'Toward a Theory of Property Rights'; Henisz, 'The Institutional Environment for Economic Growth’; North and Thomas, ‘An Economic Theory of the Growth of the Western World'; North and Thomas, The Rise of the Western World. A New Economic History; Przeworski and Limongi, ‘Political Regimes and Economic Growth’; Rodrik, 'Institutions for High-Quality Growth: What They Are and How to Acquire Them'; Ahlstrom and Bruton, 'Venture Capital in Emerging Economies: Networks and Institutional Change'; Khanna et al., 'Strategies that Fit Emerging Markets’; Khanna and Palepu, ‘Why Focused Strategies May be Wrong for Emerging Markets’; Ma et al., 'Business Group Affiliation and Firm Performance in a Transition Economy: A Focus on Ownership Voids’; Peng and Zhou, ‘How Network Strategies and Institutional Transitions Evolve in Asia’.

${ }^{4}$ Puffer et al., 'Entrepreneurship in Russia and China’; Whyte, ‘The Social Roots of China’s Economic Development’.

${ }^{5}$ Puffer et al., 'Entrepreneurship in Russia and China'.

${ }^{6}$ North, Institutions, Institutional Change and Economic Performance; North, Understanding the Process of Economic Change; North, ‘Institutions’; North, ‘Economic Performance Through Time.’ 
${ }^{7}$ North, Institutions, Institutional Change and Economic Performance; Rodrik, 'Institutions for HighQuality Growth’; Xu, ‘The Fundamental Institutions of China’s Reform and Development’.

${ }^{8}$ Baumol, ‘Entrepreneurship: Productive, Unproductive, and Destructive’.

${ }^{9}$ Smallbone and Welter, Entrepreneurship and Small Business Development in Post Socialist Economies; Sautet, ‘The Role of Institutions in Entrepreneurship’.

${ }^{10}$ Atherton and Smallbone, 'Promoting Private Sector Development in China'.

${ }^{11}$ Puffer et al., 'Entrepreneurship in Russia and China' .

${ }^{12}$ Schram, ““Economics in Command”?’, 417-420.

${ }^{13}$ Teiwes and Sun, ‘China’s New Economic Policy under Hua Guofeng’.

${ }^{14}$ Teiwes and Sun 'China’s Economic Reorientation after the Third Plenum’.

${ }^{15}$ Weatherall, Mao's Forgotten Successor: The Political Career of Hua Guofeng; Song, A Dissonance in Mao’s Revolution'.

${ }^{16}$ Dotson, 'The Confucian Revival in the Propaganda Narratives of the Chinese Government'; Wang, 'The End of the Revolution'; Wang, 'The Rise of Political Confucianism in Contemporary China'.

${ }^{17}$ Dikotter, The Tragedy of Liberation.

${ }^{18}$ Chow, Understanding China's Economy.

${ }^{19}$ ten Brink, 'Perspectives on the Development of the Private Business Sector in China'; The Economist, Bamboo Capitalism; He, 'The Development of Entrepreneurship and Private Enterprise in the People's Republic of China and Its Relevance to Transitional Economies.'

${ }^{20}$ Eesley, 'Entrepreneurship and China: History of Policy Reforms and Institutional Development'.

${ }^{21} \mathrm{Li}$ and Rozelle, 'Privatizing Rural China: Insider Privatization, Innovative Contracts and the Performance of Township Enterprises’.

${ }^{22}$ Atherton and Smallbone, 'Promoting Private Sector Development in China: The Challenge of Building Institutional Capacity at the Local Level’; Eesley, 'Entrepreneurship and China: History of Policy Reforms and Institutional Development’; Polishchuck, 'Missed Markets: Implications for Economic Behaviour and Institutional Change'; Tsai, Capitalism Without Democracy. The Private Sector in Contemporary China; Yang, 'Double Entrepreneurship in China’s Economic Reform: An 
Analytical Framework’; Yang, 'Institutional Holes and Entrepreneurship in China’; Yang,

Entrepreneurship in China.

${ }^{23}$ North, Institutions'; North, Understanding the Process of Economic Change.

${ }^{24}$ Rodrik, 'Institutions for High Quality Growth’; Sautet, ‘The Role of Institutions in Entrepreneurship: Implications for Development Policy.'

${ }^{25}$ Atherton and Smallbone, 'Promoting Private Sector Development in China: The Challenge of Building Institutional Capacity at the Local Level’; Smallbone and Welter, Entrepreneurship and Small Business Development in Post Socialist Economies.

${ }^{26}$ Polishchuck, 'Missed Markets: Implications for Economic Behaviour and Institutional Change.’

${ }^{27}$ North, ‘Epilogue: Economic Performance Through Time’; North, Understanding the Process of Economic Change; Williamson, ‘The New Institutional Economics: Taking Stock, Looking Ahead'.

${ }^{28}$ North and Weingast, 'The Evolution of Modern Institutions of Growth'.

${ }^{29}$ Atherton and Smallbone, 'Promoting Private Sector Development in China'.

${ }^{30}$ Breznitz and Murphree, Run of the Red Queen; Chen and Feng, 'Determinants of Economic Growth in China’; Demurger, 'Infrastructure and economic growth’; Liu et al., 'Relationships Between Economic Growth, Foreign Direct Investment and Trade’.

${ }^{31}$ Chen and Feng, 'Determinants of Economic Growth in China'.

${ }^{32}$ Yueh, 'What Drives China’s Growth?’.

${ }^{33}$ Rodrik et al., 'Institutions Rule'; Acemoglu et al., 'Institutions as a Fundamental Cause of LongRun Growth’.

${ }^{34}$ Puffer et al., 'Entrepreneurship in Russia and China', 451.

${ }^{35}$ Yeh, Shanghai Splendour.

${ }^{36}$ Liu, 'Revisiting Hanyeping company (1889-1908).'

${ }^{37}$ Wang, The End of the Revolution.

${ }^{38}$ Feuerwerker, ‘Ambiguity, Information Quality, and Asset Pricing’. 
${ }^{39}$ Hamilton, 'The Organizational Foundations of Western and Chinese Commerce: A Historical and Comparative Analysis'; Maddison, Chinese Economic Performance in the Long Run.

${ }^{40}$ Skinner, 'Chinese Peasants and the Closed Community: An Open and Shut Case'.

${ }^{41}$ Lin, 'The Needham Puzzle: Why the Industrial Revolution Did Not Originate in China'.

${ }^{42}$ Lehman, 'Intellectual Property Rights and Chinese Tradition Section: Philosophical Foundations’; Stone, 'What Plagiarism Was Not: Some Preliminary Observations on Classical Chinese Attitudes Toward What the West Calls Intellectual Property'.

${ }^{43}$ Lehman, 'Intellectual Property Rights and Chinese Tradition Section: Philosophical Foundations'.

${ }^{44}$ Fairbank, China: A New History.

${ }^{45}$ Bickers, The Scramble for China. Foreign Devils in the Qing Empire, 1832-1914, 62.

${ }^{46}$ Gardella, 'Squaring Accounts: Commercial Bookkeeping Methods and Capitalist Rationalism in Late Qing and Republican China’.

${ }^{47}$ Chan, ‘A Turning Point in China’s Comprador System: Kma's Changing Marketing Structure in the Lower Yangzi Region, 1912-25’.

${ }^{48}$ Elvin, The Pattern of the Chinese Past.

${ }^{49}$ Lewis, 'Economic Development with Unlimited Supplies of Labour '; Myers, 'How Did the Modern Chinese Economy Develop? - A Review Article’; Ranis and Fei, ‘A Theory of Economic Development'.

${ }^{50} \mathrm{Li}$, 'Politics and Health Care in China: The Barefoot Doctors'.

${ }^{51}$ Lampton, 'Performance and the Chinese Political System: A Preliminary Assessment of Education and Health Policies’.

${ }^{52}$ Dikotter, Mao’s Great Famine.

${ }^{53}$ Gittings, The Changing Face of China. From Mao to Market.

${ }^{54}$ Chow, China's Economic Transformation.

${ }^{55}$ Oi, 'The Role of the State in China’s Transition Economy'; Siu, Agents and Victims in South China: Accomplices in Rural Revolution.

${ }^{56}$ Weatherall, Mao’s Forgotten Successor: The Political Career of Hua Guofeng. 
${ }^{57}$ Gittings, The Changing Face of China. From Mao to Market, 100.

${ }^{58}$ Weatherall, Mao’s Forgotten Successor: The Political Career of Hua Guofeng.

${ }^{59}$ Puffer et al., 'Entrepreneurship in Russia and China'; Scott, Institutions and Organizations. Ideas and Interest.

${ }^{60}$ Atherton, 'From "Fat Pigs" and "Red Hats” to a "New Social Stratum”. The Changing Face of Enterprise Development Policy in China'; Tsai, Capitalism Without Democracy. The Private Sector in Contemporary China.

${ }^{61}$ Puffer et al., 'Entrepreneurship in Russia and China', 444.

${ }^{62}$ Atherton, 'From "Fat Pigs" and "Red Hats” to a "New Social Stratum”. The Changing Face of Enterprise Development Policy in China’.

${ }^{63}$ Puffer et al., 'Entrepreneurship in Russia and China’.

${ }^{64}$ Tsai, Capitalism Without Democracy. The Private Sector in Contemporary China.

${ }^{65}$ Tsai, Back-Alley Banking. Private Entrepreneurs in China.

${ }^{66}$ Ding et al., 'Investment and Financial Constraints in China: Does Working Capital Management Make a Difference?'

${ }^{67}$ Fagan and Zhao, 'SME Financing in China: The Current Situation, Problems and Possible Solutions'.

${ }^{68}$ Allen et al., China's Financial System: Opportunities and Challenges.

${ }^{69}$ Didier and Schmukler, The Financing and Growth of Firms in China and India. Evidence from Capital Markets.

${ }^{70}$ Zhao, Prisoner of the State. The Secret Journal of Chinese Premier Zhao Ziyang.

${ }^{71}$ Heilman, 'Policy Experimentation in China’s Economic Rise’; Li and Rozelle, 'Privatizing Rural China: Insider Privatization, Innovative Contracts and the Performance of Township Enterprises', Mertha, 'Fragmented Authoritarianism 2.0: Political Pluralisation in the Chinese Policy Process'; Nolan and Dong, Market Forces in China: Competition and Small Business - The Wenzhou Debate; Oi, ‘The Role of the State in China’s Transition Economy'; Unger and Chan, 'Inheritors of 
the Boom: Private Enterprise and the Role of Local Government in a Rural South China Township’.

${ }^{72}$ Henisz, 'The Institutional Environment for Economic Growth'; North and Thomas, The Rise of the Western World. A New Economic History; Scully, 'The Institutional Framework and Economic Development'.

${ }^{73}$ de Soto, The Mystery of Capital; de Soto, The Other Path.

${ }^{74}$ Rodrik, 'Goodbye Washington Consensus, Hello Washington Confusion? A Review of the World Bank’s Economic Growth in the 1990s: Learning from a Decade of Reform’.

${ }^{75}$ Long, 'Does the Rights Hypothesis Apply to China?'

${ }^{76}$ Atherton, 'From “Fat Pigs” and "Red Hats” to a "New Social Stratum”. The Changing Face of Enterprise Development Policy in China’; Keefer, ‘Governance and Economic Growth in China and India’; Chen et al., 'Entrepreneurs, organizational members, political participation and preferential treatment: Evidence from China’; Kielsgard and Chen, ‘The Emergence of Private Property Law in China'.

${ }^{77}$ Oi, Rural China Takes Off: Institutional Foundations of Economic Reform.

${ }^{78}$ Nolan and Paine, ‘Towards an Appraisal of the Impact of Rural Reform in China 1978-85’.

${ }^{79}$ Ash, ‘The Evolution of Agricultural Policy’.

${ }^{80}$ Weitzman and Xu, Chinese Township Village Enterprises as Vaguely Defined Cooperation; Chen, 'Does the Colour of the Cat Matter? The Red Hat Strategy in China’s Private Enterprises’.

${ }^{81}$ Chen and Rozelle, 'Leaders, Managers, and the Organization of Township and Village Enterprises in China'.

${ }^{82}$ Oi, Rural China Takes Off: Institutional Foundations of Economic Reform.

${ }^{83}$ Jefferson and Siu, 'Privatization and restructuring in China: Evidence from shareholding ownership, 1995-2001’.

${ }^{84}$ Atherton and Smallbone, 'Promoting Private Sector Development in China.'

${ }^{85}$ Puffer et al., 'Entrepreneurship in Russia and China', 453.

${ }^{86}$ Mertha, 'Fragmented Authoritarianism 2.0: Political Pluralisation in the Chinese Policy Process.' 
${ }^{87}$ Eesley, 'Entrepreneurship and China: History of Policy Reforms and Institutional Development'.

${ }^{88}$ Blecher and Shue, Tethered Deer: Government and Economy in a Chinese County; Oi, 'The Role of the State in China's Transition Economy; Unger and Chan, 'Inheritors of the Boom: Private Enterprise and the Role of Local Government in a Rural South China Township.'

${ }^{89}$ Ruf, Cadres and Kin.

${ }^{90}$ Atherton, 'From “Fat Pigs” and "Red Hats” to a "New Social Stratum”. The Changing Face of Enterprise Development Policy in China’

${ }^{91}$ Dickson, Red Capitalists in China: the Party, Private Entrepreneurs, and Prospects for Political Change.

${ }^{92}$ Dickson, Red Capitalists in China: the Party, Private Entrepreneurs, and Prospects for Political Change; Tsai, Back-Alley Banking. Private Entrepreneurs in China; Yang, 'Institutional Holes and Entrepreneurship in China’.

${ }^{93}$ Scott, Institutions and Organizations. Ideas and Interest.

${ }^{94}$ Pan, Out of Mao's Shadow. The Struggle for the New China, 21-78; Dikotter, The Tragedy of Liberation.

${ }^{95}$ Vogel, 'From Friendship to Comradeship: The Change in Personal Relations in Communist China'.

${ }^{96}$ Dikotter, The Tragedy of Liberation.

${ }^{97}$ Chang, Wild Swans; Cheng, Life and Death in Shanghai.

${ }^{98}$ Vogel, 'From Friendship to Comradeship: The Change in Personal Relations in Communist China'.

${ }^{99}$ Williamson, 'The New Institutional Economics: Taking Stock, Looking Ahead ', 597.

${ }^{100}$ Dikotter, Mao’s Great Famine.

${ }^{101}$ Dikotter, Mao’s Great Famine, 246-248.

${ }^{102}$ Dikotter, Mao’s Great Famine, 264-265.

${ }^{103}$ Dikotter, Mao’s Great Famine, 209-210.

${ }^{104}$ Dikotter, Mao’s Great Famine, 197-199.

${ }^{105}$ Vogel, 'From Friendship to Comradeship: The Change in Personal Relations in Communist China’. 
${ }^{106}$ Liu, 'Reform From Below: The Private Economy and Local Politics in the Rural Industrialization of Wenzhou'.

${ }^{107}$ Yan, 'The Flow of Gifts.'

${ }^{108}$ Yang, 'The Resilience of Guanxi and Its New Deployments: A Critique of Some New Guanxi Scholarship’.

${ }^{109}$ Guthrie, ‘The Declining Significance of Guanxi in China’s Economic Transition’.

${ }^{110} \mathrm{He}$ and Li, 'Entrepreneurial Competence and Enterprises’ Growth: An Empirical Study in China’.

${ }^{111}$ Yang, 'Institutional Holes and Entrepreneurship in China'; Yang, Entrepreneurship in China.

${ }^{112}$ Epstein and Schneider, ‘Ambiguity, Information Quality, and Asset Pricing’

${ }^{113}$ Camerer and Weber, 'Recent Developments in Modelling Preferences: Uncertainty and Ambiguity’.

${ }^{114}$ Kirzner, 'Entrepreneurial Discovery and the Competitive Market Process’.

${ }^{115}$ Atherton, ‘From “Fat Pigs” and "Red Hats” to a "New Social Stratum”. The Changing Face of Enterprise Development Policy in China’.

${ }^{116}$ Chen et al., 'Entrepreneurs, organizational members, political participation and preferential treatment: Evidence from China’.

${ }^{117}$ Broughton and Walker, 'Policies and Practices for Aquaculture Food Safety in China’; McMullin, 'Comments: Do Chinese Environmental Laws Work? A Study of Litigation as a Response to the Problem of Fishery Pollution.' 